official tests in Holland. This cable marks a very notable advance in the transmission of electric energy underground and will be most useful in the neighbourhood of towns and in populous districts. The dielectric is similar to that used in the 'solid' type of cable, but after the installation has been completed, dried nitrogen gas under pressure is admitted to the cable. The pressure used is $200 \mathrm{lb}$. per square inch and the gas finds its way along the cable in the narrow space between the dielectric and the lead sheath. All the dielectric is subjected to this pressure and so any void spaces which form in it during the working of the cable must contain gas at this high pressure. The electric strength of the void space will therefore be much greater than if the gas were absent. Very long continuous cables can be made in this way; no supplementary feed points are required. The strength required to withstand the high internal gas pressure is afforded by strengthening the lead sheath with copper tapes. The cable is treated just like the normal solid type cable during transport and installation. The point of entry of the gas is at the base of two sealing ends, and it is buried to a depth of about a yard. The cross-section of the conductor is about $0.65 \mathrm{sq}$. in. and the overall diameter is $3 \cdot 46 \mathrm{in}$. The losses in the dielectric as compared with a solid cable have been reduced by 25 per cent, and there is no increase in the losses with rise of temperature.

\section{National Institute of Sciences, India}

AT a meeting of the Council of the National Institute of Sciences of India held on November 6 the following were elected fellows of the Institute : Ordinary fellows : Prof. Y. Bharadwaja, professor of botany, Benares Hindu University, Benares; Dr. B. L. Bhatia, principal, Government College, Hoshiarpur; Prof. G. R. Paranjpe, professor of physics, Royal Institute of Science, Bombay; Dr. H. Srinivasa Rao, assistant superintendent, Zoological Survey of India, Calcutta; Dr. K. Rangadharma Rao, reader in physics, Andhra University, Waltair ; Prof. M. R. Siddiqi, professor of mathematics, Osmania University, Hyderabad-Deccan ; Prof. A. C. Sircar, professor of chemistry, Presidency College, Calcutta; Dr. M. B. Soparkar, medical officer, Plague Research Inquiry, Haffkine Institute, Parel, Bombay; Sir Shah S. Sulaiman, judge of the Federal Court of India, New Delhi; and Col. F. C. Temple, chartered civil engineer, Calcutta. Honorary fellows: Prof. Ludwig Diels, director of the Botanical Gardens, Berlin-Dahlem, Germany; Sir James G. Frazer, London ; Prof. Robert Robinson, Waynflete professor of organic chemistry, University of Oxford; Dr. C. M. Wenyon, director-in-chief, Wellcome Bureau of Scientific Research, London.

\section{The Oxford Farming Conference}

Is view of the interest aroused by the two conferences already held, the Oxford Farming Conference is to be established as an annual event. At the same time it has been decided that in future years the Conference shall not be confined to mechanized farming but shall provide a common meeting ground for farmers, research workers and others, at which any subjects of particular interest to British agriculture may be discussed. The next Conference will be held on January 4-7, 1938, and will deal mainly with the maintenance of fertility, with special reference to the Government's new agricultural policy and to the control of weeds and pests. Further information can be obtained from the Conference Secretary, 10 Parks Road, Oxford.

\section{Electron Diffraction in Crystals}

Dr. P. P. Ewald, writing from the Crystallographic Laboratory, Cambridge, with reference to the note on the Nobel Prize award to Dr. C. J. Davisson and Prof. G. P. Thomson for work on this subject (NATURE, Nov. 20, p. 882), points out that W. Elsasser predicted the effect in 1925. Elsasser's work is mentioned early in a paper by Prof. G. I. Finch and H. Wilman entitled "Study of the Surface Structure by Electron Diffraction" published in Ergebnisse der Exakten Naturwissenschaften, 16, 353436 (1937), to which reference can be made for a review of the subject. In the course of two paragraphs dealing mainly with the work of Dr. Davisson and Prof. Thomson, it was neither possible nor desirable to attempt to survey the whole field of electron diffraction.

\section{Observation of the Orionid Meteors}

MoHD. A. R. KHAN informs us that he carried out observations of this shower at Begumpet, Deccan, on October 18-20, in spite of the difficulties attending strong moonlight. Altogether he observed fortyone Orionids, and his results again confirmed the easterly movement of the radiant, the positions of which on October 18 and 20 were respectively R.A. $6^{\mathrm{h}} 5^{\mathrm{m}}$, Decl. $15^{\circ} \mathrm{N} ;$ R. A. $6^{\mathrm{h}} 15^{\mathrm{m}}$, Decl. $15^{\circ} \mathrm{N}$.

\section{Annular Eclipse of the Sun, December 2-3}

Av annular eclipse of the sun will take place on December 2-3 but will be invisible from Europe. The path of annular eclipse, which will cross the Pacific Ocean, extends from long. $139 \cdot 4^{\circ}$ E., lat. $26 \cdot 4^{\circ} \mathrm{N}$. to long. $115 \cdot 0^{\circ} \mathrm{W}$. lat. $21 \cdot 8^{\circ} \mathrm{N}$.; the respective times of beginning and ending of annular eclipse corresponding to the extremities of this path are December $2^{\mathrm{d}} 21^{\mathrm{h}} \quad 18^{\mathrm{m}}$ and December $3^{\mathrm{d}} 0^{\mathrm{h}} 52^{\mathrm{m}}$. Washington Island and Fanning Island in midPacific lie on the track, the duration of the annular phase at these places being about $11 \frac{1}{2}$ minutes.

\section{New Minor Planet close to the Earth}

Herr K. Reinmuth, Königstuhl, discovered an object, magnitude 10 , on October 28 , the position being R.A. $1^{\mathrm{h}} 34 \cdot 2^{\mathrm{m}}, \mathrm{N}$. Decl. $8^{\circ} 6^{\prime}$. It was moving rapidly-an indication of proximity to the earth. Other observations were made, but as these extended only over three days, the orbit derived is very rough. It is moving at a small inclination to the ecliptic, probably not exceeding $6^{\circ}$, and has a perihelion distance of about $0 \cdot 6$. The remarkable thing is the close approach to the earth at the end of October, namely, less than 700,000 miles. In Mon. Not. Roy. Astro. Soc., 92, 7 (May 1932), Dr. Davidson gave a 